\title{
KEBIASAAN MAKAN DAN ASUPAN ZAT GIZI MASYARAKAT HALMAHERA
}

\author{
(Food Habits and Nutrients Intake of People in Halmahera)
}

Hadi Riyadi ${ }^{1 *}$

${ }^{1 *}$ Alamat korespondensi: Departemen Gizi Masyarakat, Fakultas Ekologi Manusia, Institut Pertanian
Bogor, Bogor 16680. Telp: 0251-8621258; Fax: 0251-8622276, Email: hadiriyadi@yahoo.com

\section{ABSTRACT}

Every community develops a specific socio-cultural aspect of food. The socio-cultural factor of food reflects the food consumption pattern of social life in the community. The study was carried out to analyze food habits and nutrients intake of people in Halmahera. This research was a survey design. This research was conducted in 10 villages in Halmahera Tengah and in 3 villages in East Halmahera. Sample size $(n=304)$ was determined by simple random sampling without replacement formula. Primary data was collected in this study by interviewing respondents. The primary data was demography characteristics; food sources, preparation and processing; food taboo and preferences of children under five year old; and food consumption of households. The research showed that the communities in the research locations were agrarian communities in which their life depends on the surrounding nature. Like the population in Maluku in general, most population of Halmahera consumed sago and its processed products as its principal food sources including lempeng kasbi sago, tree lempeng sago, popeda sago, and others. The kinds of fish and foods not permitted to consume because of taboos were laying fish, nyoa fish, Rayfish, tuna, maleo and bee birds, pineapples and suanggi bananas. Some children under five liked sweet potato, taro, rice, porridge, cassava, and bananas. The average energy and protein level of sufficiency among the samples in both regencies was relatively good, except in Kobe Gunung Village and Sawai Itepo had lower level of energy and protein sufficiency than those in other villages. The nutrients with a low level of nutrient sufficiency in all villages included vitamin A, vitamin $C$ and calcium.

Key words: food habits, food taboo, nutrients intake.

\section{PENDAHULUAN}

Sepanjang sejarah manusia, penduduk yang tinggal di suatu wilayah mengembangkan cara-cara setempat, yang seringkali khas, dalam kegiatan yang berkaitan dengan pangan. Paling tidak ada tiga hal (Harper, Deaton, \& Driskel, 1985) yang mempengaruhi kebiasaan makan seseorang di suatu masyarakat, yaitu ketersediaan pangan, pola sosial budaya, serta faktor-faktor pribadi. Hampir dipastikan bahwa masyarakat pada awalnya hanya mengkonsumsi pangan yang tersedia di wilayah dia tinggal. Pola kebudayaan di suatu masyarakat akan mempengaruhi orang dalam memilih makanan, termasuk makanan tabu. Faktor-faktor pribadi, seperti pengetahuan gizi, preferansi makan dan keadaan kesehatan seseorang juga mempunyai peranan yang tidak kecil dalam mempengaruhi makanan. Sanjur (1982) menggagas model multidimensional untuk menjelaskan bahwa kebiasaan makan merupakan fungsi dari konsumsi pangan, preferensi, ideologi dan sosial budaya.
Ketersediaan pangan merupakan faktor penentu kebiasaan makan di suatu masyarakat (Suhardjo, 1989). Ketersediaan pangan ini sangat ditentukan oleh berbagai faktor, yaitu produksi pangan, pengolahan pangan, distribusi pangan, pemasakan dan peralatan. Faktor-faktor ini sangat berkaitan dengan budaya setempat (Sanjur, 1982). Karena itu budaya yang berkembang di suatu masyarakat dapat membentuk kebiasaan makan di masyarakat tertentu.

Dalam penelitian ini sangat menarik mengkaji berbagai aspek kebiasaan makan dan asupan zat gizi pada masyarakat Halmahera yang mempunyai budaya tesendiri dalam khasanah budaya Indonesia.

Tujuan yang ingin dicapai dalam penelitian ini antara lain menganalisis sumber pangan, penyiapan pangan, dan pengolahan pangan, mengidentifikasi makanan kesukaan dan makanan tabu pada anak balita, dan menganalisis asupan zat gizi penduduk 


\section{METODE}

\section{Desain dan Tempat Penelitian}

Penelitian ini merupakan penelitian survei yang dilakukan di wilayah pertambangan nikel Weda Bay, Halmahera. Lokasi penelitian meliputi dua kabupaten, yaitu Kabupaten Halmahera Tengah dan Kabupaten Halmahera Timur. Desa-Desa yang menjadi sampel di Kabupaten Halmahera Tengah adalah Fritu, Gemaf, Sagea, Lelief Sawai, Lelief Woebolen, Kobe Gunung, Sawai Itepo, Fidi Jaya, Sidanga, UPT Kobe Kulo. Desa-desa yang menjadi sampel di Kabupaten Halmahera Timur adalah Nusa Jaya, Weijoy, dan Maba Sangaji. Dengan demikian seluruhnya ada 13 desa sampel.

\section{Jumlah dan Cara Penarikan Sampel}

Besar sampel rumahtangga diambil secara proporsional dari jumlah penduduk desa dengan menggunakan formula acak lengkap sederhana (Cochran, 1982) dengan asumsi dari studi Sukandar (2006) keragaman asupan zat gizi 771 kilokalori/kapita/hari (s=771) dan akurasi 79.9 serta taraf kepercayaan 95\%, maka didapatkan besar sampel 304 rumahtangga.

\section{Jenis, Pengolahan, dan Analisis Data}

Jenis data yang dikumpulkan adalah karakteristik demografi rumahtangga, sumber pangan, penyiapan dan pengolahan pangan, makanan kesukaan dan tabu anak balita, serta konsumsi pangan rumahtangga. Data karakteristik demoggrafi dikumpulkan dengan cara wawancara menggunakan kuesioner. Data sumber, penyiapan, dan pengolahan pangan dikumpulkan dengan cara wawancara menggunakan kuesioner pada rumahtangga, serta dengan cara wawancara mendalam (indepth interview) terhadap tokoh masyarakat. Makanan kesukaan dan tabu pada anak balita dikumpulkan dengan wawancara menggunakan kuesioner. Data konsumsi pangan rumahtangga diperoleh dengan cara recall 24 jam.

Pengolahan dan analisis data dilakukan dengan menggunakan SAS. Disamping itu juga dilakukan analisis secara deskriptif terhadap hasil wawancara mendalam.

\section{HASIL DAN PEMBAHASAN}

\section{Karakteristik Rumahtangga}

Umur suami dan istri di Kabupaten Halmahera Tengah dan Halmahera Timur tergolong kelompok usia produktif (15-64 tahun).
Rata-rata umur suami di Kabupaten Halmahera Tengah adalah 40.0 tahun, sedangkan kisaran umurnya adalah 34.5 - 43.6 tahun. Rata-rata umur suami di Kabupaten Halmahera Timur (39.0 tahun) sedikit lebih muda dibandingkan umur suami di Kabupaten Halmahera Tengah, kisaran umurnya adalah 38.3 - 40.7 tahun. Rata-rata umur istri di Kabupaten Halmahera Tengah lebih muda lima tahun dibandingkan umur suami. Rata-rata umur istri adalah 34.7 tahun, dengan kisaran 30.9 - 38.5 tahun. Sementara itu, di Kabupaten Halmahera Timur rata-rata umur istri adalah 36.4 tahun, yang artinya lebih muda tiga tahun dibandingkan umur suami, dengan kisaran antara 35.8 - 37.2 tahun.

Tingkat pendidikan seseorang dapat dilihat berdasarkan lamanya atau jenis pendidikan yang dialami seseorang. Tingkat pendididikan suami di Kabupaten Halmahera Tengah dan Halmahera Timur masih tergolong rendah karena rata-rata pendidikan suami adalah lulusan SD dan SMP. Jumlah suami di Kabupaten Halmahera Tengah yang lulus sekolah dasar (SD) sebesar $46.9 \%$ dan lulus Sekolah Menengah Pertama (SMP) sebesar 25.4\%. Meskipun sangat sedikit, namun ada juga yang meneruskan pendidikan ke perguruan tinggi (1.9\%). Begitu pula di Kabupaten Halmahera Timur, suami dengan pendidikan lulusan SD dan SMP sebesar $41.6 \%$ dan $28.6 \%$, tetapi tidak ada suami yang lulus perguruan tinggi. Rendahnya tingkat pendidikan dan kualitas pendidikan orang-orang Indonesia, termasuk di lokasi penelitian, membuat mereka tak bisa bersaing di bursa tenaga kerja yang semakin kompetitif (IFPPD, 2006).

Pendidikan istri tidak berbeda jauh dengan tingkat pendidikan suami. Pendidikan istri di Kabupaten Halmahera Tengah dan Halmahera Timur umumnya masih rendah. Di Kabupaten Halmahera Tengah istri lulusan SD berjumlah $51.9 \%$ dan lulusan SMP sebesar $24.3 \%$. Ada juga istri yang berpendidikan sampai perguruan tinggi yaitu sebesar $1.4 \%$. Begitu pula di Kabupaten Halmahera Tengah istri yang lulus SD dan SMP masing-masing sebesar $46.4 \%$ dan $23.8 \%$. Pendidikan istri di Kabupaten Halmahera Tengah lebih tinggi dibandingkan suaminya, karena ada istri yang mencapai jenjang perguruan tinggi, yaitu sebesar $3.6 \%$. Walaupun sudah lebih dari 90\% panduduk Indonesia mengenyam tingkat pendidikan dasar 6 tahun tapi yang bisa melanjutkan pendidikannya ke sekolah lanjutan pertama, sekolah menengah atas dan perguruan tinggi sangat sedikit. Hambatan utama yang dihadapi adalah kemiskinan. Walaupun pemerintah sudah memberlakukan wajib belajar 9 tahun dan membebaskan 
uang sekolah serta memberi berbagai kemudahan dan beasiswa, tapi kemiskinan membuat banyak keluarga memutuskan untuk tidak menyekolahkan anak-anaknya lebih lanjut. Hal ini dapat dipahami mengingat sekolah tidak hanya sekedar membayar uang sekolah tapi juga membeli pakaian seragam, biaya transport, uang jajan dan pungutan sekolah (IFPPD, 2006).

Dalam hal mata pencaharian umumnya masyarakat di Kabupaten Halmahera Tengah dan Halmahera Timur manjadikan sektor pertanian sebagai sandaran hidup utama. Hal ini terlihat dari hasil penelitian yang menunjukkan hampir sebagian besar suami $160.3 \%$ di Halmahera Tengah dan 57.1\% di Halmahera Timur) bekerja sebagai petani. Komoditi yang ditanam masyarakat Halmahera Tengah antara lain kelapa, singkong, ubi jalar dan lainnya. Petani transmigran banyak menanam padi dan sayuran (BPS, 2007). Selain bekerja sebagai petani, sebagian suami di Halmahera Tengah dan Timur ada yang bekerja sebagai buruh (11.0\% dan $6.5 \%)$, dan karyawan swasta $(6.2 \%$ dan $10.4 \%$. Masih sedikitnya lapangan usaha dalam menyerap tenaga kerja lokal dipengaruhi tingkat pendidikan dan keterampilan kerja yang masih rendah. Dalam skala mikro, tenaga kerja dengan tingkat ketermpilan yang paspasan, atau bahkan rendah, hanya bisa menempati posisi yang sangat rendah. Ditambah dengan banyaknya supply tenaga kerja yang tersedia menyebabkan mereka tidak memiliki posisi tawar yang memadai (Tjiptoherijanto, 2001).

Sebagian besar istri di Kabupaten Halmahera Tengah dan Kabupaten Halmahera Timur adalah ibu rumahtangga $160.3 \%$ dan $54.8 \%)$. Sebagian lainnya bekerja di sektor pertanian atau menjadi petani yaitu sebesar $33.6 \%$ dan $35.7 \%$. Hal tersebut karena umumnya mereka berpendidikan rendah atau hanya lulusan SD sehingga tidak bisa bekerja di bidang lain yang membutuhkan keahlian lebih.

Di Halmahera Tengah dan Halmahera Timur rata-rata ukuran rumahtangga adalah 4.7 dan 4.5 orang. Ini berarti setiap rumahtangga hanya memiliki 2-3 anak. Keluarga-keluarga muda umumnya sudah menyadari pentingnya menjadi peserta keluarga berencana (KB). Dengan pembatasaan kelahiran, mereka berharap dapat meningkatkan kesejahteraan keluarga.

\section{Sumber, Penyiapan dan Pengolahan Pangan}

Masyarakat di daerah penelitian ini pada umumnya bekerja di sektor pertanian dan sebagian kecil bekerja sebagai nelayan dan lainnya. Karena itu mereka merupakan masyarakat agraris yang dalam kehidupan sehari-hari sangat tergantung dengan alam disekitarnya. Pola pertanian yang paling dominan adalah berladang dan berkebun. Tanaman perkebunan yang yang diusahakan adalah pala, kelapa, dan cengkeh. Tanaman pangan yang diusahakan adalah sagu, pisang, singkong, padi, ubi jalar, kacang tanah, kacang panjang, buah-buahan dan sayur-sayuran. Sebagian masyarakat masih melakukan aktivitas berburu dan pengumpul hasil pertanian dari hutan sekitar. Menurut penuturan tokoh masyarakat, beberapa hewan yang diburu adalah beberapa jenis burung seperti burung taun, burung maleo, burung kumkum dan burung siba, serta madu tawon dan kijang. Masyarakat juga sudah biasa mengambil tanaman hutan untuk dimakan atau dijual, seperti pohon-pohonan, buah-buahan dan sayuran, serta bunga anggerik. Tanaman yang diambil untuk dijual adalah rotan, kayu, bambu, pala dan anggerik. Tanaman yang biasa dimakan yang diambil dari hutan adalah ubi tali (biasanya terdapat di dalam tanah dengan kedalaman 20-30 cm, ubinya seperti ubi kayu), bete (ubi seperti talas) sayur ujung muda batang rotan, jamur kayu (putih), pisang dan jantung pisang (dari pisang yang banyak bijinya), rebung bambu, sayur gulubeng (seperti pohon pinang yang diambil umbutnya), okire (umbutnya), pohon goluba (buah dan ujung batang), buah rofis (seperti manggis berasa manis), buah gora (seperti jambu berwarna putih), buah langsat, buah mangga. Tanaman hutan juga ada yang diambil sebagai obat, seperti goluba (selain sayur juga obat luka), batang moa (obat luka dan menghentikan pendarahan), benalu (untuk sakit perut, sakit kerongkongan dan badan terasa sakit), bunga balong (warna kuning untuk obat sakit gigi), dan bunga kengkong (obat gatal-gatal).

Sumber pangan yang biasa dikonsumsi penduduk diperoleh dengan berbagai cara. Ada yang diproduksi sendiri (dibuat sendiri), dibeli, banter dan diperoleh dari alam sekitar. Cara memperoleh sagu, baik berupa lempeng sagu maupun popeda sagu diperoleh dengan cara dibuat/diproduksi sendiri secara tradisional, kecuali di desa-desa yang lebih maju (terbuka) perolehan dengan cara pembelian sudah mulai mendominasi cara perolehan sagu tersebut, seperti di Fidi Jaya, Lelief Sawai, Lelief Weibulan. Pengolahan pohon sagu menjadi sagu pada saat ini dilakukan secara tradisional (menggunakan tenaga manual untuk memotong dan memarutnya) serta secara moderen (menggunakan mesin untuk memotong dan 
menyerutnya). Penggunaan mesin menghasilkan sagu yang lebih banyak, tetapi mengurangi kesempatan penggunaan tenaga lokal. Sagu yang diperoleh tersebut selanjutnya diolah menjadi sagu lempeng dengan cara dibakar dan popeda sagu dengan cara merendam tepung sagu selama lima (5') menit kemudian diangkat dan disiram dengan air panas. Makanan lain berbahan dasar sagu adalah "baggea" yang merupakan makanan jajanan/selingan. Baggea jarang dibuat di rumah-rumah penduduk karena prosesnya yang banyak membutuhkan tenaga dan biaya. Baggea dalam pembuatannya membutuhkan bahan-bahan yang relatif mahal menurut ukuran masyarakat setempat, seperti gula, karena itu pembuatannya jarang dilakukan selain juga masalah pengolahannya yang terlalu berat (butuh waktu dan tenaga ekstra). Pembuatan baggea saat ini dilakukan oleh industri rumahtangga, yang dijual untuk masyarakat setempat atau sebagai buah tangan (oleh-oleh). Baggea biasanya dimakan dengan minum teh manis atau kopi.

Sagu biasanya disimpan dalam ember, karung atau wadah/anyaman yang terbuat dari daun sagu. Mereka menjelaskan tidak ada metode untuk mengawetkan makanan pokok tersebut. Dengan metode penyimpanan tradisional tersebut sagu bisa disimpan 6 bulan sampai satu tahun.

Beras juga dikonsumsi penduduk setempat, beras pada umumnya diperoleh dengan cara dibeli, kecuali di Kobe Gunung sudah banyak masyarakatnya yang memproduksi beras sendiri. Harga beras cukup mahal karena itu tidak semua penduduk mengonsumsi beras, kecuali kaum pendatang serta anak-anak yang sudah mulai menyukai makan nasi. Beras diolah dulu menjadi nasi dengan cara ditanak atau direbus menjadi bubur sebelum dimakan.

Singkong juga merupakan makanan yang sering dikonsumsi. Singkong pada umumnya diperoleh dengan cara diproduksi/dibuat sendiri. Singkong yang dikonsumsi sebagai makanan sehari-hari berupa singkong rebus, singkong goreng, swami (kukusan parutan singkong) atau sagu kasbi lempeng. Oleh karena itu dari wawancara terlihat kebiasaan masyarakat yang menggoreng atau merebus singkong. Khusus untuk popeda kasbi dan lempeng kasbi cara pengolahannya sama dengan popeda dan lempeng sagu.

Selain sagu masyarakat disini juga sudah biasa mengkonsumsi nasi (beras) sebagai makanan pokoknyameskipun masih relatif kecil. Namun demikian, kalangan muda (anak) lebih menyukai nasi sebagai makanan pokoknya. Singkong juga dikonsumsi sebagai makanan sehari-hari berupa singkong rebus, singkong goreng, swami (kukusan parutan singkong) atau sagu kasbi lempeng. Beberapa kalangan masyarakat juga mengkonsumsi ubi jalar bentuk rebus ataupun goreng Pisang juga dijadikan makanan pokok. Pisang matang (masak) diolah menjadi pisang santan (pisang masak direbus dengan santan dan dimakan dengan ikan), sedangkan pisang goreng diolah dari pisang masak atau setengah masak (mangkel) yang digoreng tanpa atau pakai tepung.

Jagung yang biasa dikonsumsi masyarakat pada umumnya diperoleh melalui produksi sendiri dan membeli dari pasar sekitar. Jagung tidak dikonsumsi sebagai makanan pokok melainkan hanya sebagai makanan selingan atau sebagai sayur. Pada umumnya jagung dimasak dengan cara direbus tetapi sebagian dimasak sebagai sayur melalui proses penggorengan atau penumisan (tumis).

Ubi jalar pada umumnya diperoleh dengan cara memproduksi sendiri atau dibeli, hanya sebagian kecil saja yang mendapatkannya langsung dari hutan sekitar. Ubi jalar juga hanya dimakan sebagai makanan selingan atau sebagai sayur. Proses pengolahan makanan selingan sangat sederhana, hanya dengan penggorengan dan atau perebusan. Hasil olahnya hanya berupa ubi rebus atau ubi goreng. Sayur ubi juga biasa disajikan oleh masyarakat dalam bentuk semacam sayur bening berbahan dasar ubi jalar.

Talas juga biasa dikonsumsi masyarakat. Talas biasanya diperoleh melalui produksi sendiri atau membeli di pasar terdekat, segelintir masyarakat memperolehnya dari hutan sekitar. Talas diproses sederhana melalui penggorengan dan perebusan menjadi ubi goreng atau ubi rebus, hanya sebagian kecil masyarakat yang mengolahnya dengan cara dikukus.

Makanan lain yang juga dikonsumsi penduduk adalah mie, roti dan biskuit. Makanan ini berbahan dasar tepung terigu. Makanan tersebut pada umumnya diperoleh dengan cara membeli di warung. Mie biasanya diolah dengan cara perebusan atau penggorengan menjadi mie rebus atau mie goreng. Roti dan biskuit biasanya langsung dikonsumsi tanpa proses pengolahan lebih lanjut.

Masyarakat sekitar umumnya mengonsumsi ikan sebagai pelengkap makanan pokok. Ikan diperoleh dari hasil memancing atau menjala di laut atau di sungai. Ikan (hasil) laut yang biasa dikonsumsi adalah ikan laut dalam 
(cakalang, tuna, kembung), batu, teri, udang, cumi-cumi, kepiting, kerang-kerangan. Beberapa hasil laut juga diambil untuk dijual seperti teripang dan Bia Lola (kerang yang diambil kulitnya untuk dijual dan isinya dimakan), serta akar bakar. Sebelum dikonsumsi ikan diolah terlebih dahulu. Pengolahan ikan yang paling sering dilakukan adalah dengan cara digoreng. Selain itu ikan juga dibakar dan direbus. Ikan rebus atau masak kuah merupakan teman makan sagu lempeng. Pangan hewani lain yang juga dikonsumsi adalah ayam, burung, ulat sagu dan babi (untuk masyarakat beragama kristin).

Sayur-sayuran juga biasa dikonsumsi masyarakat. Sayur-sayuran yang dikonsumsi cukup bervariasi, tetapi yang dikonsumsi biasanya sayuran yang berasal dari wilayah setempat, seperti daun singkong, bayam, sawi, terong, daun papaya, tomat, kangkung, nangka muda, rebung, bunga papaya, buah papaya muda, kacang panjang, kemangi (balakama), rebung, cabe, bawang merah, jantung pisang, jamur kayu, sayur ujung rotan (sulurnya), umbut-umbut pohon dihutan (gulubeng, okire, goluba), kelapa (santan). Sayuran tersebut pada umumnya dimakan dalam bentuk sudah dimasak (Tabel 1). Pemasakan yang dilakukan adalah sekedar direbus atau direbus dengan santan. Kebiasaan penggunaan santan dalam memasak sayur ini dlakukan oleh sekitar separuh rumahtangga di daerah penelitian ini, bahkan untuk desa Sidanga dan Lelief Sawai mencapai lebih dari tigaperempat rumahtangga (Tabel 2).

Tabel 1. Sebaran Rumahtangga menurut Kebiasaan Makan Sayur Mentah atau Masak

\begin{tabular}{lcccc}
\hline \multirow{2}{*}{ Tempat* $^{*}$} & \multicolumn{2}{c}{ Masak } & \multicolumn{2}{c}{ Mentah } \\
\cline { 2 - 5 } & $\mathrm{n}$ & $\%$ & $\mathrm{n}$ & $\%$ \\
\hline HALMAHERA TENGAH & & & & \\
Lelief Sawai & 17 & 73.9 & 6 & 26.1 \\
Lelief Waibulan & 18 & 72.0 & 7 & 28.0 \\
Kobe Gunung & 11 & 91.7 & 1 & 8.3 \\
Sawai Itepo & 10 & 83.3 & 2 & 16.7 \\
Fidi Jaya & 28 & 84.8 & 5 & 15.2 \\
Sidanga & 10 & 83.3 & 2 & 16.7 \\
Kobe Kulo & 25 & 80.6 & 6 & 19.4 \\
& 119 & 80.4 & 29 & 19.6 \\
HALMAHERA TIMUR & & & & \\
Nusajaya & 39 & 95.1 & 2 & 4.9 \\
Waijoi & 24 & 100.0 & 0 & 0.0 \\
Maba Sangaji & 17 & 89.5 & 2 & 10.5 \\
\multicolumn{1}{c}{ TotTAL } & 80 & 95.2 & 4 & 4.8 \\
& 199 & 85.8 & 33 & 14.2 \\
\hline
\end{tabular}

*)Di desa Fritu, Gemaf dan Sagea tidak dikumpulkan data kuantitatif ini, karena adanya perbaikan kuesioner.
Tabel 2. Sebaran Rumahtangga menurut Sering Tidaknya Masak Sayuran dengan Santan

\begin{tabular}{lcccc}
\hline \multirow{2}{*}{ Tempat* $^{*}$} & \multicolumn{2}{c}{ Ya } & \multicolumn{2}{c}{ Tidak } \\
\cline { 2 - 5 } & $\mathbf{n}$ & $\%$ & $\mathbf{n}$ & $\%$ \\
\hline HALMAHERA TENGAH & & & \\
Lelief Sawai & 18 & 78.3 & 5 & 21.7 \\
Lelief Waibulan & 17 & 68.0 & 8 & 32.0 \\
Kobe Gunung & 5 & 41.7 & 7 & 58.3 \\
Sawai Itepo & 7 & 58.3 & 5 & 41.7 \\
Fidi Jaya & 16 & 48.5 & 17 & 51.5 \\
Sidanga & 9 & 75.0 & 3 & 25.0 \\
Kobe Kulo & 15 & 48.4 & 16 & 51.6 \\
$\quad$ Sub Total & 87 & 58.8 & 61 & 41.2 \\
HALMAHERA TIMUR & & & & \\
Nusajaya & 21 & 51.2 & 20 & 48.8 \\
Waijoi & 11 & 45.8 & 13 & 54.2 \\
Maba Sangaji & 10 & 52.6 & 9 & 47.4 \\
$\quad$ Sub Total & 42 & 50.0 & 42 & 50.0 \\
$\quad$ TOTAL & 129 & 55.6 & 103 & 44.4 \\
\hline
\end{tabular}

*)Di desa Fritu, Gemaf dan Sagea tidak dikumpulkan data kuantitatif ini, karena adanya perbaikan kuesioner.

Masyarakat tidak memiliki tempat penyimpanan khusus untuk sayuran. Kalaupun menyimpan mereka hanya menyimpan sayuran di ruang terbuka biasa sesuai dengan daya tahan simpan sayuran pada suhu ruang. Tampaknya mereka tidak tiap hari menyediakan sayuran untuk konsumsi keluarganya.

Buah-buahan juga biasa dikonsumsi meskipun tidak setiap hari, seperti buah pisang, jambu biji, nenas, nangka masak, jeruk, kedondong dan pepaya. Selain itu juga ada buahbuahan yang dikonsumsi tidak setiap hari melainkan hanya pada musimnya saja, seperti mangga, jambu air, rambutan, langsat, durian, kweni, manggis, sawo, salak, buah rofis, gora, dan lain-lain. Buah-buahan ini biasanya diperoleh dari kebun, halaman sekitar rumah ataupun dari hutan sekitar, sebagian juga ada yang dibeli. Buah-buahan ini biasanya dimakan dalam bentuk segar. Pada umumnya buah dimakan dalam keadaan segar, kecuali pisang matang yang kadang-kadang digoreng, dibuat kolak atau dimasak santan sebagai makanan pokok.

Masyarakat juga tidak mempunyai tempat penyimpanan khusus untuk buah-buahan. Di samping itu mereka juga tidak mempunyai cara khusus untuk mengawetkan buah-buahan. Daya awet buah-buahan semuanya tergantung pada daya tahan simpan buah di suhu ruang. Mereka biasanya memanen buah secara 
bertahap sesuai dengan tahapan kematangan buah di pohon buah yang mereka miliki.

\section{Makanan Kesukaan dan Tabu Anak Balita}

Makanan yang disukai anak balita cukup beragam. Ada anak balita yang menyukai ubi jalar karena makanan tersebut memang menjadi salah satu makanan pokok di lokasi penelitian sehingga mungkin orang tuanya menyajikan ubi jalar untuk seluruh anggota keluarga hampir tiap hari. Selain itu, talas juga disukai balita. Talas seperti halnya ubi jalar juga biasa dikonsumsi anggota rumahtangga sebagai salah satu pangan pokok. Beberapa jenis makanan pokok lain yang disukai balita adalah nasi, bubur, singkong, dan pisang. Minuman teh juga disukai anak balita. Seperti halnya masyarakat Indonesia pada umumnya, minum teh seringkali sudah menjadi kebiasaan. Namun, di kotakota besar kebiasaan minum teh kini mungkin sudah digantikan air mineral yang banyak tersedia di pasaran.

Makanan asal pabrik yang disukai anak balita adalah wafer tango dan mie instant. Makanan-makanan ini tidak hanya dapat dijumpai di kota tetapi juga di desa-desa. Akses orang desa terhadap makanan modern akhirnya menjadi lebih mudah, dan mungkin dapat mempengaruhi kebiasaan makannya.

Pantangan atau tabu adalah suatu larangan untu mengkonsumsi jenis makanan tertentu, karena terdapat ancaman bahaya atau hukuman terhadap seseorang yang melanggar- nya (Suhadjo, 1989). Anak-anak balita dilarang makan ikan asin karena menyebabkan batuk. Jenis ikan lain yang juga tidak boleh dimakan karena tabu adalah: ikan laying, ikan nyoa, ikan pari, ikan tuna dll. Beberapa jenis burung juga dianggap tabu untuk dikonsumsi karena kepercayaan yang diwariskan turun-temurun dari orang tua atau alasan-alasan lain seperti dapat menyebabkan sakit lepra. Burung-burung yang dianggap taboo untuk dimakan antara lain: burung maleo dan burung tawon bu ah yang dianggap tabu dan tidak boleh dimakan adalah nanas dan pisang suanggi, namun dalam hal ini responden tidak menyebutkan alasan mengapa kedua jenis buah tersebut dilarang. Banyaknya jenis makanan sumber protein hewani yang ditabukan bagi anak balita tersebut menyebabkan pilihan pangan sumber hewani semakin sedikit, dikhawatirkan hal ini akan mempengaruhi status gizi anak balita.

\section{Asupan Zat Gizi Rumahtangga}

\section{Asupan Zat-zat Gizi}

Jenis dan jumlah zat gizi yang dikonsumsi penduduk Halmahera Tengah dan Halmahera Timur tergantung pada jenis dan jumlah pangan yang dikonsumsi. Dari tabel di bawah ini terlihat bahwa kecuali protein dan fosfor, asupan zat-zat gizi sampel di wilayah Halmahera Tengah lebih tinggi dibandingkan asupan gizi di wilayah Halmahera Timur. Perbedaan yang cukup besar di antara kedua kabupaten terlihat pada energi, vitamin A, dan kalsium.

Tabel 3. Asupan Zat Gizi per Kapita/hari

\begin{tabular}{|c|c|c|c|c|c|c|c|c|}
\hline \multirow[b]{2}{*}{ Lokasi } & \multicolumn{8}{|c|}{ Asupan Zat Gizi } \\
\hline & $\begin{array}{l}\text { Energi } \\
\text { (kkal) }\end{array}$ & $\begin{array}{l}\text { Protein } \\
\text { (g) }\end{array}$ & $\begin{array}{c}\text { Vit. A } \\
(\mu \mathrm{g})\end{array}$ & $\begin{array}{l}\text { Vit. B } \\
\text { (mg) }\end{array}$ & $\begin{array}{l}\text { Vit. C } \\
\text { (mg) }\end{array}$ & $\begin{array}{c}\text { Kalsium } \\
\text { (mg) }\end{array}$ & $\begin{array}{c}\text { Phosphor } \\
\text { (mg) }\end{array}$ & $\begin{array}{l}\text { Besi } \\
(\mathrm{mg})\end{array}$ \\
\hline \multicolumn{9}{|l|}{ HALMAHERA TENGAH } \\
\hline Fritu & 1405.5 & 31.5 & 239.3 & 0.4 & 28.3 & 134.1 & 425.4 & 3.0 \\
\hline Gemaf & 1589.0 & 36.9 & 449.6 & 1.2 & 38.4 & 177.1 & 492.5 & 4.1 \\
\hline Sagea & 1517.3 & 38.7 & 273.1 & 0.8 & 23.1 & 119.2 & 542.8 & 4.3 \\
\hline Lelilef Sawai & 1541.1 & 48.3 & 363.8 & 1.2 & 12.9 & 396.3 & 713.2 & 5.1 \\
\hline Lelilef Weibulen & 1713.0 & 63.2 & 392.9 & 1.1 & 30.8 & 198.1 & 768.8 & 5.0 \\
\hline Kobe Gunung & 1187.5 & 23.2 & 168.9 & 0.3 & 36.6 & 149.7 & 393.7 & 4.1 \\
\hline Sawai Itepo & 861.4 & 24.7 & 582.3 & 0.7 & 94.2 & 120.5 & 293.6 & 3.6 \\
\hline Fidi Jaya & 1547.4 & 45.2 & 258.4 & 1.0 & 14.3 & 225.5 & 735.0 & 4.9 \\
\hline Sidanga & 1824.0 & 42.4 & 217.6 & 0.5 & 31.9 & 71.1 & 622.2 & 4.3 \\
\hline UPT Kobe Kulo & 1332.6 & 41.9 & 294.0 & 0.5 & 34.4 & 181.7 & 622.3 & 4.0 \\
\hline Sub Total & 1487.7 & 42.1 & 323.3 & 0.8 & 30.1 & 187.8 & 599.7 & 4.4 \\
\hline \multicolumn{9}{|l|}{ HALMAHERA TIMUR } \\
\hline Nusa Jaya & 1635.2 & 50.0 & 229.3 & 1.0 & 23.7 & 94.0 & 680.9 & 4.6 \\
\hline Weijoy & 1292.9 & 30.8 & 294.5 & 0.7 & 31.9 & 146.7 & 503.1 & 3.8 \\
\hline Maba Sangaji & 1394.7 & 51.5 & 224.6 & 1.7 & 28.7 & 128.3 & 708.1 & 5.2 \\
\hline Sub Total & 1483.0 & 44.9 & 246.8 & 1.1 & 27.2 & 116.8 & 636.2 & 4.5 \\
\hline Total & 1486.4 & 42.9 & 302.1 & 0.9 & 29.3 & 168.2 & 609.8 & 4.4 \\
\hline
\end{tabular}


Asupan energi sampel terutama didapatkan dari konsumsi nasi dan sagu. Tabel 3 di bawah menunjukkan bahwa asupan energi yang rendah $(<1000 \mathrm{kkal})$ terjadi di wilayah Desa Sawai Itepo. Dibandingkan dengan data konsumsi sebelumnya, terlihat bahwa konsumsi beras maupun sagu di wilayah Sawai Itepo tampak paling rendah dibandingkan desa lainnya, sehingga berpengaruh terhadap jumlah asupan energi yang juga lebih rendah dibandingkan desa lainnya.

Jumlah asupan protein yang rendah terlihat di Desa Kobe Gunung dan Sawai Itepo, yaitu kurang dari $30 \mathrm{mg} / \mathrm{kap} /$ hari. Protein sampel terutama didapatkan dari pangan ikan, sementara pangan sumber protein lainnya seperti daging unggas dan ruminansia serta kacangkacangan tampak kurang berpengaruh. Berdasarkan tabel tentang konsumsi ikan diketahui bahwa total konsumsi ikan sampel di Desa Kobe Gunung relatif lebih rendah dibandingkan desa lainnya.

\section{Tingkat Kecukupan Gizi}

Sebagaimana asupan gizi, tingkat kecukupan semua jenis zat gizi di Kabupaten Halmahera Tengah secara rata-rata lebih baik dibandingkan dengan tingkat kecukupan gizi sampel di Kabupaten Halmahera Timur (Tabel 4). Rata-rata tingkat kecukupan energi dan protein sampel di kedua kabupaten cukup baik. Adapun berdasarkan desa, tampak bahwa penduduk di Desa Kobe Gunung dan Sawai Itepo memiliki tingkat kecukupan energi dan protein yang lebih rendah dibandingkan desa lainnya. Hal tersebut sejalan dengan konsumsi pangan sumber energi (serealia) dan protein (daging, ikan, kacang-kacangan) di kedua desa yang juga lebih rendah.

Meskipun demikian, dari tabel juga terlihat bahwa zat gizi yang memiliki tingkat kecukupan gizi yang rendah di semua desa adalah vitamin A, vitamin C, dan kalsium. Vitamin A terutama banyak terdapat pada sayuran buah dan buah-buahan, vitamin C pada buah-buahan, sementara kalsium banyak terdapat pada daging-dagingan dan susu. Sebagaimana telah dibahas pada bagian sebelumnya, konsumsi sayuran buah, buah-buahan dan daging-dagingan di semua desa, baik Halmahera Tengah maupun Halmahera TImur tergolong sangat rendah.

\section{KESIMPULAN}

Masyarakat Halmahera merupakan masyarakat agraris, yang dalam kehidupannya sangat tergantung pada alam sekitarnya. Pendidikan mereka masih tergolong rendah, umumnya hanya lulus SD.

Makanan pokok mereka adalah sagu yang dipadu dengan ikan, yang pengolahannya hanya terbatas dibakar dan direbus. Makanan tersebut tersedia di lingkungan sekitar, meskipun demikian beras sudah mulai mendominasi makanan sehari-hari.

Tabel 4. Tingkat Kecukupan Gizi (\%)

\begin{tabular}{|c|c|c|c|c|c|c|c|c|}
\hline Lokasi & Energi & Protein & Vit. A & Vit. B & Vit. C & Kalsium & Phosphor & Besi \\
\hline \multicolumn{9}{|l|}{ HALMAHERA TENGAH } \\
\hline Fritu & 86.2 & 90.1 & 49.0 & 79.4 & 42.5 & 22.1 & 89.3 & 23.0 \\
\hline Gemaf & 87.9 & 82.6 & 85.4 & 145.0 & 56.3 & 26.0 & 84.3 & 24.9 \\
\hline Sagea & 81.0 & 80.2 & 44.3 & 108.2 & 25.4 & 17.1 & 90.9 & 24.7 \\
\hline Lelilef Sawai & 105.7 & 121.6 & 75.7 & 173.6 & 19.4 & 85.1 & 162.1 & 33.4 \\
\hline Lelilef Weibulen & 100.1 & 105.8 & 64.7 & 153.5 & 35.2 & 33.2 & 110.6 & 23.8 \\
\hline Kobe Gunung & 56.2 & 43.6 & 26.3 & 27.0 & 42.1 & 16.4 & 64.7 & 23.7 \\
\hline Sawai Itepo & 58.3 & 60.1 & 78.8 & 75.9 & 113.1 & 15.2 & 68.4 & 27.1 \\
\hline Fidi Jaya & 89.0 & 93.6 & 48.1 & 120.8 & 21.4 & 31.4 & 126.0 & 31.1 \\
\hline Sidanga & 87.2 & 82.2 & 40.2 & 48.5 & 44.5 & 9.0 & 91.0 & 26.9 \\
\hline UPT Kobe Kulo & 81.7 & 95.4 & 39.6 & 79.8 & 35.5 & 25.6 & 115.7 & 27.9 \\
\hline Sub Total & 85.7 & 89.2 & 55.1 & 111.7 & 37.4 & 29.9 & 105.9 & 27.1 \\
\hline \multicolumn{9}{|l|}{ HALMAHERA TIMUR } \\
\hline Nusa Jaya & 77.5 & 92.1 & 37.4 & 100.5 & 28.8 & 11.1 & 101.4 & 25.5 \\
\hline Weijoy & 65.2 & 60.2 & 54.8 & 62.6 & 47.1 & 19.4 & 84.1 & 21.8 \\
\hline Maba Sangaji & 73.4 & 107.4 & 42.9 & 163.5 & 39.7 & 17.2 & 119.5 & 32.4 \\
\hline Sub Total & 73.1 & 86.4 & 43.6 & 103.9 & 36.5 & 14.9 & 100.5 & 26.0 \\
\hline Total & 82.2 & 88.4 & 52.0 & 109.6 & 37.1 & 25.8 & 104.4 & 26.8 \\
\hline
\end{tabular}


Makanan yang disukai anak balita cukup beragam, yaitu ubi jalar, talas, nasi, bubur, singkong, dan pisang.

Jenis makanan tabuuntuk anak balita adalah ikan laying, ikan nyoa, ikan pari, ikan tuna,burung maleo dan burung tawon, serta buah nanas dan pisang suanggi.

Rata-rata tingkat kecukupan energi dan protein penduduk Halmahera relatif baik, kecuali di Desa Kobe Gunung dan Sawai Itepo. Zat-zat gizi tingkat kecukupannya masih rendah adalah vitamin $\mathrm{A}$, vitamin $\mathrm{C}$ dan kalsium.

\section{UCAPAN TERIMA KASIH}

Peneliti mengucapkan termakasih atas bantuan Prof. Dr. Ali Komsan, Prof. Dr. Dadang Sukandar, Leily Amalia, M.Si, dan Arina Rizkiana, SP, serta enumerator dari Poltekkes Ternate. Terimakasih juga kami ucapkan pada Environmental Resource Management (ERM) dan PT Weda Bay Nickel yang telah mendanai penelitian ini. Tentu saja penelitian ini tidak dapat terlaksana tanpa bantuan dan kesediaan bapak/ibu responden dan kepala desa, untuk itu kami ucapkan terimakasih. Begitu pula ucapan terimakasih pada Pimpinan Fakutas Ekologi Manusia dan Departemen Gizi Masyarakat IPB yang banyak memfasilitasi penelitian ini

\section{DAFTAR PUSTAKA}

BPS. 2007. Maluku Utara Dalam Angka 2007. http: //haltengkab.go.id /index.php? option=com_content\&task=view\&id=3
Cochran WG. 1982. Sampling Technique. John Wiley and Son, New York.

den Hartog AP, Van Staveren WA, \& Brouwer ID. 2006. Food Habits and Consumption in Developing Countries: Manual for Field Studies. Wageningen Academic Publishers, Netherlands.

IFPPD (Indonesian Forum of Parliamentarians on Population and Development). 2006. Globalisai dan Kualitas Penduduk Indonesia. http://www.ifppd.org/detailnews .php?id=8.

Tjiptoherijanto P. 2001. Proyeksi Penduduk, Angkatan Kerja, Tenaga Kerja, dan Peran Serikat Pekerja dalam Peningkatan Kesejahteraan. Majalah Perencanaan Pembangunan. Edisi. 23. Tahun 2001. www.bappenas.go.id/get-fileserver/node/8602/.

Harper LJ, Deaton BJ \& Driskell JA. 1985. Pangan, Gizi dan Pertanian. (Penerjemah Suhardjo). UI Press, Jakarta.

Sanjur D. 1982. Social and Cultural Perspectives in Nutrition. Prentice, New York.

Suhardjo. 1989. Socio-Culture of Nutrition. Department of Education and Culture. Directorate General of Higher Education. Inter University Center for Food and Nutrition, IPB, Bogor.

Sukandar D. 2006. Study of Socio-economy, Food, Nutrition and Sanitation Aspect in Banjar West Java, Barito Kuala South Kalimantan, Jeneponto South Sulawesi, Lombok Tengah West Nusa. 